\title{
Development of a National Curriculum for Pre-School Childcare Institutions in Estonia
}

\author{
Tiia Õun
}

\begin{abstract}
The purpose of this article is to provide an overview of the development of the national curriculum of pre-school institutions in Estonia from 1990 to 2004, which also reflects broader changes in the system of Estonian pre-school education. The development of the curriculum is analysed on the basis of legislation and other documents. When Estonia was part of the Soviet Union, it had to follow All-Union programmes. However, in 1968, an original curriculum was introduced in Estonian institutions that had to follow only some general aspects of Soviet programmes. After the restoration of Estonian independence in 1991, new development of the national curriculum began. Significant influence on the development of the curriculum was the implementation of the 'Good Start' programme in 1994 and other non-mainstream programmes. The National Early Childhood Curriculum for pre-school childcare institutions implemented in 1999 set its main goal as the promotion of the child's comprehensive development in cooperation with the home and the childcare institution. Unlike during the Soviet era, childcare institutions began to develop their own curricula based on their pedagogical specialties. In 2002, a study of the curricula revealed several problems in pre-school education such as lack of emphasis on play and time constraints in planning and integrating activities. In 2004, a new and improved curriculum for early childhood education began to be developed. It can be concluded that the development of a curriculum for pre-school childcare institutions in Estonia from 1990-2004 was a democratic process, supported by applied research and leaders of teachers' groups. The Primary Education Framework Programme, implemented in 1999, supported the processes of democratisation of education and the implementation of a child-centred approach in pre-school childcare institutions in Estonia.
\end{abstract}

Keywords: pre-school education, curriculum, Estonia

\section{Introduction}

The question of what pre-school curricula should be is one of the central topics of discussion in contemporary pre-school pedagogy. The curriculum is a comprehensive document throughout the ages, supporting the work of teachers and ensuring smooth transition from kindergarten to school. The goals set for substantive activities show what the pedagogical concept of the childcare institution is and how child-centred education principles are considered in education activities. Internationally, new innovative approaches, such as the use of information technology, have been highlighted, but at the same time, innovations often re-design existing methods and give them new names. The content of pre-school curriculum depends on how the child's development, 
the meaning of education, and the role of the teacher in supporting child development are understood by the public. Thus, curriculum content of preschool education depends on trends in education itself and education in society.

In post-socialist countries such as Estonia, discussions about kindergarten curriculum have been very active in recent decades because since regaining independence, the organisation and content of pre-school education throughout the country has changed in a short period of time. Early childhood education in Estonia developed in the context of European education, and the beginning of pre-school childcare institutions can be seen in 1840 when the first childcare institution was opened in Estonia. ${ }^{1}$ The first national kindergarten was opened in Tartu in 1905. ${ }^{2}$ During the first Republic of Estonia (1918-1940), no legislative acts were passed on kindergartens. In this regard, Estonia was left behind by several countries where kindergartens were legally regulated. When Estonia was occupied by the Soviet Union, Soviet education programmes began to operate in the entire educational system. However, from 1968 until 1987, many kindergartens worked under a specially designed national curriculum. ${ }^{3}$

The purpose of this article is to present an overview of the development of the state curriculum of Estonian pre-school childcare institutions from 19902004. The process of curriculum development is examined in light of trends affecting pre-school education, mainly on content analysis of legislation and other documents.

\section{Development of curriculum for pre-school childcare institutions from 1991 to 1999}

As background to curriculum development, it is important to bear in mind the creation of new laws and the impact of economic and demographic change in the entire field of nursery and pre-school education.

After restoration of independence, a new code of education was implemented, which was a time-consuming and difficult process. On 23 March 1992, the Education Act was passed. ${ }^{4}$ The following year, four new laws were adopted;

1 S. Annist, 'Väikelaste hoiuasutus - Tallinna esimene lasteaed?' [Early childhood institution the first kindergarten in Tallinn?], in Vana Tallinn [Old Tallinn], vol. 10, no. 14, Tallinn, Tallinna Linnavalitsus, 2000.

2 M. Torm, 'Lasteaednike koolituse kujunemine Eestis' [Formation of kindergarten teachers training], in U. Kala (ed.), Võimalus ja paratamatus olla õpetaja [An opportunity and a necessity to be a teacher], Tallinn, TPÜ Kirjastus, 1997, pp. 203-210.

3 S. Silinciske, M. Torm, V. Jonite, 'An Overview of Kindergarten Development in Lithuania, Latvia and Estonia,' in I. Kestere, A. Kruze (eds.), History of Pedagogy and Educational Sciences in the Baltic Countries from 1940 to 1990: an Overview, Riga, RaKa, 2013, pp. 31, 35-36.

4 'Eesti Vabariigi haridusseadus' [Education Act of the Republic of Estonia], Riigi Teataja [State Gazette], vol. 12, no. 192, 1992. Available: https://www.riigiteataja.ee/akt/30588 (accessed 1 April 2020). 
the Law on Pre-school Childcare Institutions was adopted on 9 June 1993. To regulate the activities of pre-school childcare institutions, a new Law on Preschool Childcare Institutions was passed in 1999, which modernised the legal basis for the activities of childcare institutions: tasks, types, number of children per group, organisation of study activities, financing, teacher responsibility, and assessment. ${ }^{6}$ The law stipulated that pre-primary childcare institutions in Estonia are educational institutions that children under the age of 7 can attend. The obligation to provide pre-primary education was given to local authorities; it was also possible to create private institutions. The Estonian language was designated as the language of instruction, but, if necessary, Russian-speaking groups could also be opened.

At the end of the Soviet era in 1990, the birth rate began to drop and the number of children's institutions decreased as a result. If in 1990 there were 767 pre-school childcare institutions in Estonia, then by 2003 there were only 597, of which 26 were private kindergartens (see Table 1). At the same time, the proportion of children attending pre-school childcare institutions increased in corresponding age groups. According to the Statistics Office of Estonia (see Table 1), in $2002,31.8 \%$ of children aged 1 to 2 and $74.6 \%$ of 3 -year-old children attended kindergarten. ${ }^{7}$

Table 1. Pre-school education statistics 1990-2003

\begin{tabular}{|l|c|c|c|c|c|c|}
\hline \multicolumn{1}{|c|}{ Indicators } & $\mathbf{1 9 9 0}$ & $\mathbf{1 9 9 5}$ & $\mathbf{2 0 0 0}$ & $\mathbf{2 0 0 1}$ & $\mathbf{2 0 0 2}$ & $\mathbf{2 0 0 3}$ \\
\hline Pre-school institutions & 767 & 671 & 646 & 642 & 596 & 597 \\
\hline Enrolled children (thousands) & 81,9 & 60,9 & 50,6 & 49,9 & 49,6 & 51,3 \\
\hline $\begin{array}{l}\text { Percentage of children in childcare } \\
\text { institutions aged 1-6 }\end{array}$ & 57 & 56 & 67 & 67 & 67 & 69 \\
\hline $\begin{array}{l}\text { Percentage of children aged 3 to 6 in } \\
\text { childcare institutions }\end{array}$ & 68 & 65 & 79 & 80 & 80 & 83 \\
\hline
\end{tabular}

A number of reorganisations have been made in the system of preschool childcare institutions since 1991. Pre-school childcare institutions no longer were under state management and financing but "belonged" to local governments. Laws were passed for the establishment of private kindergartens. Changes in ownership caused financing problems and, to some extent, also resulted in a decrease in the number of childcare institutions.

5 'Koolieelse lasteasutuse seadus' seadus' [Pre-school Establishments Act], Riigi Teataja [State Gazette], vol. I-40, no. 593, 1993. Available: https://www.riigiteataja.ee/akt/680867 (accessed 1 April 2020).

6 'Koolieelse lasteasutuse seadus' [Pre-school Establishments Act], Riigi Teataja [State Gazette], vol. I-27, no. 387, 1999. Available: https://www.riigiteataja.ee/akt/77275 (accessed 1 April 2020).

7 'Eesti Statistikaamet' [Statistical Office of Estonia]. Available: http://pub.stat.ee/px-web. 2001/I_ Databas/Social_life/02Education/12Preprimary_education/12Preprimary_education.asp (accessed 10 April 2017). 
On 20 August 1991, Estonia regained its independence. The main direction of change in pre-school education in 1991-1999 was to replace the collectivist education system typical of the Soviet era with a child-centred approach, taking into account the child's individuality and to create the necessary legal regulations for the activities of childcare institutions. ${ }^{8}$

Curriculum development processes are influenced by broader political trends in society. In the Soviet Union, there were uniform educational programmes for all pre-school institutions. The main goal of educational activities was ideological - communist education, which consisted of collectivism, labour, ${ }^{9}$ and patriotic education. In general, Soviet era pre-school pedagogy was characterised by learning activities for which the same curriculum and methods were used throughout the USSR. There were no private educational institutions, and the heads of educational institutions had no opportunity to independently create curriculum. ${ }^{10}$ In each Soviet republic, some local preferences could be adapted to the pre-school education programme. In all levels of education in Estonia, the language of instruction was Estonian and textbooks in Estonian were used (except for institutions and schools for Russian-speaking children). However, dissemination of child-centred and democratic ideas was rather difficult and unwelcome.

It should be emphasised that as in many other fields of education, Soviet Estonia achieved a certain degree of freedom in pre-school education by establishing kindergarten programmes and teaching aids. The programme created by the then Minister of Education of the ESSR Ferdinand Eisen (1914-2000) and a more than a 10-member working group was published and adopted (in Estonian) by childcare facilities in $1968 .{ }^{11}$ In following decades, it was continuously supplemented both substantively and methodologically, partly due to the need to adhere to the main All-Union precepts (e.g., Russian language instruction in kindergartens) and partly due to methodological work of Estonian teachers and specialists. At the end of the 1980s, Estonian kindergartens used

\footnotetext{
${ }^{8}$ K. Kööp, 'Estonia: Socio-historic and Political Influences on the Early Childhood Education and Care System,' in J. Georgeson, J. Payler (eds.), International Perspectives on Early Childhood Education and Care, Open University Press, McGraw-Hill Education, 2013, pp. 64-75; A. Ugaste, T. Oun, 'History and Current Situation in the Estonian Early Childhood Education, in U. Härkönen, E. Savolainen (eds.), International Views on Early Childhood Education, Joensuu, University of Joensuu, 2008. Available: http://sokl.uef.fi/verkkojulkaisut/varhais/kehys.htm (accessed 10 April 2017).

9 J. Tudge, 'Education of Young Children in the Soviet Union: Current Practice in Historical Perspective,' The Elementary School Journal, no. 92, 1991, pp. 121-133.

${ }^{10}$ A. Ugaste, T. Õun, 'History and Current Situation in the Estonian Early Childhood Education, in U. Härkönen, E. Savolainen (eds.), International Views on Early Childhood Education, Joensuu, University of Joensuu, 2008. Available: http://sokl.uef.fi/verkkojulkaisut/varhais/kehys.htm (accessed 10 April 2017).

${ }^{11}$ S. Silinciske, M. Torm, V. Jonite, 'An Overview of Kindergarten Development in Lithuania, Latvia and Estonia,' in I. Kestere, A. Kruze (eds.), History of Pedagogy and Educational Sciences in the Baltic Countries from 1940 to 1990: an Overview, Riga, RaKa, 2013, p. 35.
} 
the programme 'Pre-school education in childcare institutions' ${ }^{12}$ published in 1987. In this programme, Communist education, without which adoption of the programme would have been impossible, was interpreted as collective and labour-related education. But unlike the All-Union programmes, play took the leading role in the Estonian programme. Explanation of labour-related education covered one and a half pages with explanations of Introducing surrounding life, Introducing nature, Speech development, Children's literature, Development of elemental mathematical imagery, Construction, Imagination activities, Musical education, and Physical education. That was the very content of the programme.

This curriculum-development practice created the basis for subsequent innovations in the 1980s and 1990s, using existing ideas, experts, and practitioners.

With the re-establishment of independence, Soviet laws and programmes lost their validity. It took time to draft new laws, and each kindergarten had to prepare the necessary basis for itself. As a basis for activities in kindergartens, former Soviet programmes, experience from other countries, and alternative pedagogies were considered. Simultaneously, pedagogical ideas prohibited during the Soviet era were re-discovered. The most well-known was the methodology of Estonian school innovator and enthusiast of Reformpädagogik who was active in pre-war Estonia Johannes Käis' (1885-1950) complex teaching/learning system. Käis compiled a methodology of general teaching for schools, but his ideas were well adapted to kindergartens. The complex teaching/learning system is based on child psychology. Käis presented principles of childhood, the need to consider the child's development and interests, and emphasised the need for integration of school subjects. Käis' approach to general education was based on domestic culture, the basis of which was theme-based integration of teaching and individualisation of student work. ${ }^{13}$ Many Estonian kindergartens adopted Käis' principles when compiling their curricula.

In the 1990s, in addition to the Käis method, kindergarten teachers were interested in various global pedagogical trends. Many went abroad to study practices of other countries. The teachers were keenly interested in Montessori and Waldorf pedagogy and went to observe and study those methodologies abroad. ${ }^{14}$ Since 1988, many short and some long-term (up to 4 years) courses have been organised in Estonia using Montessori, Waldorf and Freinet pedagogy

${ }^{12} \mathrm{H}$. Sarapuu et al. Koolieelsest kasvatusest lasteasutuses [Preschool education in a preschool establishment], Tallinn, Valgus, 1987.

${ }^{13}$ J. Käis, Isetegevus ja individuaalne tööviis [Self-activity and individual work], Tallinn, Koolibri, 1992.

${ }^{14}$ From 1990-1994, several books for teachers and parents were published in Estonian on Montessori and Waldorf methodologies, e.g., I. Meister, Avastagem laps. Montessori pedagoogika [Let's discover the child. Montessori pedagogy], Tallinn, Valgus, 1994; K. Lukk, Waldorfpedagoogika 1. osa [Waldorf-pedagogy. Chapter 1], Tallinn, Harjumaa Arenduskeskus, 1991. 
principles that were attended by pre-school teachers as well. ${ }^{15}$ Teachers began to apply those elements, but there were few kindergartens during this period in which the curriculum was based entirely on Montessori or Waldorf pedagogy.

In general, during the first decade of independence, the pedagogical range of children's institutions and teacher skills expanded and the general approach became more child-centred.

\section{Implementation of the 'Good Start' programme}

In Estonia, the 'Step by Step' (Hea algus) programme began in 1994 and influenced the development of curriculum at the national level and kindergartens that adopted the programme as the basis for their activities. The purpose of the programme was to support development of democracy and child-centred ideas in educational institutions of the former Soviet Union. ${ }^{16}$ The goal was to increase family participation in child rearing and support an individualised approached to education in kindergarten, which would help children to develop democratic skills, including the ability to make choices. The theoretical foundations of the Step-by-Step programme included approaches to the development and learning of the child, the growth environment, and the need for and implementation of democratic principles in pre-school. The programme also included principles for developing a group growth environment, monitoring children's development, and assessing, personalising, and co-working with parents. ${ }^{17}$

While in the earlier Soviet-era programmes, a great deal of collectivist, uniform education was emphasised, implementation of the Good Start methodology was important in individualising teaching, creating a childcentred learning environment, positive communication between the teacher and the child, assessing the child's development, and working with parents. Child-centred individualisation meant that the daily plan was tailored to the needs of each child, and selected materials, teaching methods, and activities had to be appropriate for everybody. The role of the teacher was seen as comprehensive support for development of the child through individualisation and involvement of the family in assessment of the child's development and the activities of the group. An important principle the Good Start programme started to implement in Estonian kindergartens was the use of the environment as part of the learning process. A good learning environment allows the child to make choices, to realise his or her interests, and to act pro-actively. Following this principle, Estonian childcare institutions began to create activity centres in

\footnotetext{
${ }^{15}$ E-S. Sarv, Demokraatiast ja humanismist õpetajale: Eesti haridusuuendus - hariduse demokratiseerumine ja humaniseerumine [On democracy and humanism to teacher: Estonian educational renewal - democratisation and humanisation of education], Tallinn, Riiklik Eksami-ja Kvalifikatsioonikeskus, 1997.

${ }^{16} \mathrm{~K}$. Hansen, et al., Hea Alguse lasteaedade programmem ['Step by Step' kindergarten programme], Tallinn, Avatud Eesti Fond, 1997.

${ }^{17}$ Ibid.
} 
the classrooms, which enabled the teacher to individualise activities and children to actively learn, play, make choices, and act in small groups in the classroom. The teacher played an important role in implementing the programme and was responsible for creating a suitable environment for the development of each child, which meant knowing the child's strengths, needs, and interests.

In 1994, 22 Good Start groups began operation. The first teachers' groups were trained in the USA. The aim was to design model groups for introducing Good Start methodology more widely. In 1996, a number of Estonian schools joined Good Start and introduced it into 13 first grades. In 1997, Russianlanguage schools were also included in the programme. By 2004, Good Start was implemented by nearly 250 kindergarten groups and 150 classrooms across Estonia. The programme was supported by the Good Start Training Centre. In addition to Good Start kindergarten teachers, many child day-care teachers from other kindergartens participated. Materials for nursery teachers were provided to conduct democratic education in kindergartens, to implement Good Start methodology programmes, and to offer recommendations for assessing the activities of teachers. Good Start programme ideas were, to a large extent, used in the national early childhood education curriculum.

International studies have shown that participation in the Step by Step programme positively impacted the emotional, social, and intellectual development of children and supported the spread of child-centred ideas among teachers. ${ }^{18}$

In Estonia, relatively little research has been carried out on the implementation of the Good Start programme. Studies among kindergarten teachers have shown that the implementation of Good Start supports the professional development of teachers and helps teachers better understand and analyse pedagogical processes and child development. ${ }^{19}$ Also, Good Start teachers assess their child-centred approach more highly than do "ordinary" kindergarten teachers. ${ }^{20}$

\section{Implementation of pre-school education institution curriculum, 1999-2004}

The National Curriculum for Basic Schools and Upper Secondary Schools was adopted in 1996 (based on projects developed in 1987, 1989, 1994), but it took more time for preschool institutions. Only in 1996 was the Pre-School

${ }^{18}$ E. M. Kazimade, et al., 'Evaluation of the Step by Step Programme in Azerbaijan', Educating Children for Democracy, no. 5, 2003, pp. 25-31; M. Havlinova, et al., 'Measuring Psychosocial Outcomes in the Step by Step Programme,' Educating Children for Democracy, no. 6, 2004, pp. 20-25.

19 A. Ugaste, T. Õun, 'Teachers' Experiences in Child-Centered Education in Estonia,' Young Children, vol. 62, no. 6, 2003, pp. 54-56.

${ }^{20}$ T. Oun, et al., 'Perception of Estonian Preschool Teachers About the Child-cantered Activities in Different Pedagogical Approaches,' European Early Childhood Education Research Journal, vol. 18, no. 3, 2010, pp. 241-256. 
Curriculum Project released, with difficulty. The project was implemented and tested and feedback was received; it ultimately became the National Curriculum for Pre-school Children's Institutions in 1999.

Discussions on the development of curriculum were very intense after 1991. In 1999, the National Pre-school/Elementary Education Framework was implemented, requiring each kindergarten to draw up a curriculum. The main purpose of educational activities in kindergartens was to support children's physical, mental, and social development so that children could cope with everyday life and learning in school. These main aims were also reflected in the new edition of the curriculum..$^{21}$

The 1999 Curriculum defined the main principles and organisation of learning activities: cooperation with parents, taking into account a child's individuality, appreciation of Estonian culture and other cultures, the importance of play, physical activity, and options/choices. The Curriculum defined fields of learning: language and speech, mathematics, art, music, and movement. The number of activities per week was also defined; for example, 3- to 5-yearold children had to have art activities 2 to 3 times a week. The duration of activities was also defined: for children under 3-10-15 minutes, 3-5 years old up to 25 minutes; and for 6-7-year-old children - up to 35 minutes. It included recommended topics, descriptions of subject areas, and the basis for assessing a child's development and expected results at the age of 3, 5, and 7 years.

Similarities between the 1999 Curriculum and earlier Soviet programmes did exist: the overall goal of kindergarten was to promote the development of the child in all fields with special attention paid to strengthening health and monitoring development. Among the differences were most notably the introduction of individualisation in the curriculum, which meant that the earlier emphasis on collectivist education was replaced by support for the child's individuality, and each kindergarten could draw up its curriculum based on the nature of the kindergarten and its children. The second difference was that the 1999 Curriculum was not oriented solely for preparation for school but for broader preparation of children for life. The third difference was the approach to cooperation with parents: kindergarten was a family-supported institution, not an example of training and upbringing as in the past.

The role and tasks of pedagogical staff working in kindergartens is important for implementation of the curriculum. In the Soviet era, pedagogical staff were appointed as nursery school educators, but in the new child-centred curriculum, kindergarten staff would support the individual development of each child. The Pre-school Establishments Act stipulated that pedagogues working in childcare institutions should counsel parents on educational issues. The change in the status of kindergarten staff was apparent in the change of title from 'educator' to 'teacher' in 1999. But this did not mean that the salary

\footnotetext{
21 'Alushariduse raamõppekava kinnitamine' [Approval of the framework curriculum for preprimary education], Riigi Teataja [State Gazette], vol. I-80, no. 737, 1999. Available: https://www. riigiteataja. ee/akt/77809 (accessed 1 April 2020).
} 
of a kindergarten teacher would be equal to that of schoolteachers. ${ }^{22}$ Kindergartens were owned by municipalities and financed from local budgets; thus, the salaries of kindergarten teachers varied considerably from region to region. During the Soviet era, specialised secondary education was required to become a kindergarten teacher, but after regaining independence, qualification requirements for teachers were changed and kindergarten teachers were now required to have higher pre-school pedagogy degrees or at least specialised secondary education qualifications. Kindergarten heads and deputies needed a higher education degree.

Comparing the Estonian Pre-School/Elementary Education Framework with other European countries during the same period, the Estonian curriculum was designed for children 0-7 years old, as in Denmark, Finland, Norway, and Sweden. The curriculum was similar to that of other Nordic countries, which were also oriented towards the overall development of children by emphasising humanist, democratic values and in which teachers shared responsibility for children's development. ${ }^{23}$ Comparison of the main objectives of pre-school curriculum in other European Union countries, ${ }^{24}$ reveals that the goals were similar: the child's comprehensive development, autonomy, responsibility, and cooperation and dialogue with parents were prioritised. ${ }^{25}$

\section{Language immersion}

The aim of language immersion is equally good skills in the mother tongue, the target language, and in other languages.

The aim of the Estonian language immersion programme is acquisition of functional skills of both languages - the language of instruction and the mother tongue. The programme was implemented mostly in Russian kindergartens and schools in 2000. This meant that schools, in addition to the home, provided children with an environment and culture in their mother tongue. Language immersion pupils studied their mother tongue, literature, and culture. ${ }^{26}$ The first language immersion groups in kindergartens for Russian-speaking children opened in 2003.

The immersion programme required increased teacher readiness to support and improve learning for non-Estonian children, including mastery of culturally sensitive teaching methods in a multicultural, multi-lingual classroom. Teachers had to improve their knowledge, skills, and experience in long-term and

22 'Koolieelse lasteasutuse seadus' [Pre-school Establishments Act], Riigi Teataja [State Gazette], vol. I-27, no. 387, 1999. Available: https://www.riigiteataja.ee/akt/77275 (accessed 1 April 2020).

${ }^{23}$ M. Alvestad, I. Pramling Samuelsson, 'a Comparison of the National Preschool Curricula in Norway and Sweden, Early Childhood Research \& Practice, vol. 1, no. 2, 1990. Available: http:// ecrp.uiuc.edu/v1n2/alvestad.html (accessed 20 March 2017).

${ }^{24}$ European Commission, Key Data on Education in Europa, Luxembourg, Eurostat, 2002.

25 'Koolieelse lasteasutuse riiklik õppekava' [National curriculum for preschool establishments], Riigi Teataja [State Gazette], vol. I-23, no. 152, 2008. Available: https://www.riigiteataja.ee/ akt/13351772 (accessed 1 April 2020).

${ }^{26} 15$ aastat keelekümblust [15 Years of language immersion], SA Innove, 2014, pp. 9, 18, 21, 22. 
extensive continuing education (e.g., Integrated Teaching in the Language Immersion Group; Teaching Estonian as a Secondary at pre-school childcare institutions). ${ }^{27}$

In the case of language immersion, the holistic principle was especially important in Estonian curricula. Holism attempts to shape the whole person through the whole curriculum. This meant that the pupil had to be prepared to deal with various learning, working, and living situations. It also meant integration of different parts of the curriculum. In a holistic curriculum, continuity, sequence, and integration are central principles. ${ }^{28}$ Continuity means that there is vertical repetition in the curriculum: skills and concepts should be repeated and there should be opportunities for practicing them. Subsequently, the curriculum should support the development of understanding, and each subsequent experience builds on the previous, becoming broader and deeper. Integration requires a complete picture of the subject being studied. ${ }^{29}$ The effectiveness of the achievement of the objectives of the curriculum is assessed with the increase of competence.

The Longitudinal Study 2007-2009 examined the achievements of preprimary and third grade primary-school students who studied using early immersion methodology. Both teachers and parents assessed the achievements of children at the end of kindergarten and the third grade. The ratings differed slightly but were quite positive and showed that kindergarten language immersion groups prepared children well for school in all areas of competences. Learning in Estonian language immersion classes was also successful. ${ }^{30}$

\section{Applied research and development activities of the curriculum}

In 2002, under the guidance of the Estonian Ministry of Education and Research, a study was conducted to assess the implementation of the curriculum.

\footnotetext{
${ }^{27}$ A. Kukk, et al., Varane keelekümblus: õppekava eesmärkide saavutamine lapsekeskse lähenemise aspektist [Early language immersion: achievement the goals of the curriculum in terms of a child-centered approach], Tallinn, Haridus- jA Teadusministeerium \& Tallinna Ülikool, 2012, pp. 10, 42.

${ }^{28}$ T. Kuusk, 'Lõiming. Lõimingu võimalusi põhikooli õppekavas' [Integration. The possibilities of the integration in the basic school curriculum], 2010, p. 6. Available: http://www.ut.ee/ curriculum/orb.aw/class=file/action=preview/id=724571/L\%F5 imingukogumik.pdf. (accessed 1 March 2010); A. Kukk, 'Õppekava eesmärkide saavutamine üleminekul lasteasutusest kooli ning I kooliastmes õpetajate hinnanguil' [Achievement of the objectives of the curriculum in the transition from pre-school institution to school as assessed by the teachers at I schoollevel], PhD diss., Tallinn University, 2010; T. Õun, 'Koolieelse lasteasutuse kvaliteet lapsekeskse kasvatuse aspektist' [The quality of preschool from the aspect of child-centered education], PhD diss., Tallinn University, 2011.

${ }^{29}$ A. Kukk, et al., Varane keelekümblus: õppekava eesmärkide saavutamine lapsekeskse lähenemise aspektist [Early language immersion: achievement the goals of the curriculum in terms of a child-centered approach], Tallinn, Haridus- ja Teadusministeerium \& Tallinna Ülikool, 2012, pp. 16-17.

${ }^{30}$ Ibid., pp. 8, 144, 147.
} 
The aim was to provide feedback from leaders and teachers of kindergartens about the possibilities and problems of implementing the national curriculum. ${ }^{31}$ The study showed that teachers were pleased with the opportunity to create a curriculum for their kindergarten classes. Additionally, content of the learningareas/subject-areas in the curriculum provided teachers with the opportunity to choose topics and activities, and the overall structure of the curriculum was appreciated.

However, leaders and teachers raised a number of issues in implementing the pre-school education curriculum. First, modernisation of the goals and principles of learning was necessary. The 1999 Framework Curriculum outlined the goals in general terms. Children's individuality and specificity were emphasised, but the objectives were formulated from the viewpoint of the teacher: the teacher teaches, explains, develops, etc. Considering the principles of a child-centred approach, teachers found that the goals and principles of the curriculum needed to be modernised.

The curriculum provided the number of educational activities per week based on the age of the children. Most pedagogues found that this did not support implementation of integrated teaching and various child-centred practices. This was particularly emphasised by supporters of alternative pedagogical trends and the Step by Step programme. Teachers pointed out that the importance of play was not highlighted enough in the curriculum, adding that it was necessary to emphasise the role of play in education and activities and highlight the children's play skills separately. The curriculum outlined the principles for teaching but lacked a broader learning concept - how to understand the learning processes of a pre-school child and which learning approaches/concepts the teacher would apply. The leaders and teachers who participated in the study stated that the wording of the curriculum did not support implementation of a child-centred learning approach. Teachers also stated that the curriculum needed be more open to support the development of special needs children with cooperation from parents, organisation of teaching Estonian language as a second language, and issues of ethical, health, and emotional education. The results of children's development at the age of 3,5, and 7 years were presented in the framework. Teachers found that it would be necessary to specify the descriptions of these results at each age stage by areas. It was also pointed out that the developmental results for the kindergarten curriculum did not adhere to school curriculum; therefore, when updating the curriculum, the outcomes for children aged 6-7 should be coordinated with the basic school curriculum. ${ }^{32}$

Based on the research, the representatives from of the Ministry of Education and Research, including teachers, leaders, representatives of professional associations, parents, and university specialists created working groups in

\footnotetext{
${ }^{31} \mathrm{~J}$. Treier, 'Alushariduse õppekava rakendumine' [Implementation of the Early Childhood Curriculum], Thesis, University of Tartu, 2004.

${ }^{32}$ Ibid.
} 
2004. The aim of these groups was to supplement and update the Pre-school Framework Curriculum based on previous research and international preschool education documents. The updated curriculum took effect in 2008.

\section{Conclusion}

After the restoration of independence of Estonia in 1991, democratic principles were revalued in the field of education. Openness to educational renewal was present in Estonian society in the early 1990s. Educationalists and practitioners were interested in alternative pedagogical trends, such as Waldorf and Montessori pedagogy. The organisation of pre-school institutions was based on children's development, unlike during the Soviet period when educational institutions were characterised predominantly by teacher-led and controlled learning processes. Emphasis was placed on child-friendliness instead of the authoritarian style, which ignored the needs and interests of the child. ${ }^{33}$ Yet, principles of child-centred approach were not unknown in Estonia in the earlier periods. In the 1930s under the leadership of Johannes Käis, many Estonian schools implemented integrated teaching and individualisation, and after reestablishment of independence, many kindergartens began to redefine Käis' principles.

The main topics of discussion on the development of the pre-school education programme since 1991 have been related to the consideration and assessment of a child's development, integration of teaching, and flexibility of the curriculum. The implementation of the Good Start programme in Estonian kindergartens since 1994 has made a significant impact on the development of the national curriculum and the activities of educational and educational childcare institutions: more attention is paid to the child's individuality, group work, design of child-centred group space, provision of options, and implementation of democratic teaching methods.

In 1999, the Frame Curriculum for Pre-school Education (as in the curricula of the ESSR) promoted the development of the child and paid attention to strengthening the child's health. The curriculum emphasised the child's individuality and integration of learning activities more than before. It also created the opportunity for childcare institutions to draw up their own curricula, which supported the specificity of each individual childcare institution and inclusion of pedagogical staff in the development of the curriculum. Teaching and upbringing was not narrowly oriented to academic knowledge and preparation for school, but to a broader scope of daily life.

Research on the implementation of curriculum completed in 2002 revealed that, according to the teachers, there were no clear learning and teaching concepts defined in the pre-school education curriculum. Also, play was not

\footnotetext{
${ }^{33}$ E. S. Sarv, 'Political and Social Transformations - Analysis in the Estonian Context', in H. Niemi (ed.), Moving Horizons in Education. International Transformations and Challenges of Democracy, Helsinki, University of Helsinki, 1999, pp. 39-67.
} 
sufficiently emphasised and planning of the learning process was subjectoriented and hindered the use of integrated teaching methods. Studies indicate that a rigid programming system limited teacher activities and application of various methodologies. Due to the results of the research, curriculum development was launched, which resulted in completion of the curriculum for Estonian pre-school institutions in 2008.

To conclude, the development of a curriculum for pre-school childcare institutions in Estonia in the years 1990-2004 was a democratic process, supported by research, group leaders, and teachers. The Primary Education Framework Programme, implemented in 1999, supported democratisation of education and implementation of a child-centred approach in pre-school childcare institutions in Estonia.

Acknowledgements. Many thanks go to Mare Torm for review and substantive additions and refinements. 